\title{
Comparison of the geranium (Pelargonium) pathological results of 2016-2017
}

\author{
Viktor József Vojnich - Adrienn Szarvas \\ University of Szeged, Faculty of Agriculture, Institute of Plant Sciences and Environmental Protection, Hódmezővásárhely, Hungary \\ vojnich.viktor@mgk.u-szeged.hu
}

\begin{abstract}
SUMMARY
The research was carried out in a Gyenes Flower gardening between 2016 and 2017 in Kecskemét. The gardening was founded in 1978. Initially, the main plants were gerbera (Gerbera) and yucca (Yucca), later replaced by the geranium (Pelargonium) cultivation as a result of market demand. In horticulture, there are about than 80 variety geranium of the standing, running, semi-trailer types and English gnawing. The Pelargonium had different sizes and colors. The study was set up in 1,000-1,000 pieces of geraniums each year. The following pathogens have damaged the geranium stock: Botrytis cinerea, Pythium debaryanum, with a rare occurrence of Alternaria porri, Phytophthora cryptogea. The greatest destruction was caused by botrytis (Botrytis cinerea). In the first experimental year, $42 \%$ of the 1,000 geraniums tested were infected with fungal diseases $(30 \%$ B. cinerea, $8 \%$ P. debaryanum, 4\% other fungi). In 2017, fungal infections were detected on 380 geraniums in the 1,000 tested geraniums (290 Botrytis cinerea, 70 Pythium and 20 other fungal diseases). In addition to the use of fungicides, we increased the spatial position of geraniums, early irrigation and frequent ventilation to ensure successful control. By 2017, we were able to reduce the damage caused by pathogens by 4 percent.
\end{abstract}

Keywords: Geranium (Pelargonium), Botritys cinerea, garden, fungicide, 2016-2017

\section{INTRODUCTION}

The geranium (Pelargonium) is part of the Geraniaceae family. Among the genus of the geranium there are annual or perennial herbaceous species, rarely woody (semi-shrubs or shrubs) (Nagy, 1975; Honfi et al., 2011). The most common species is the garden geranium (Pelargonium hortorum) (Szántó et al., 2003). To Europe, the first geranium (Pelargonium triste) was imported by the Dutch around 1600 from South Africa.

Today, the cultivated geranium species are of hybrid origin. The bloom depending on the variety and the season lasts 20-40 days. Geranium is an extraneous pollinating plant. In the geranium home country (South Africa), pollen mediated by the birds, while in Hungary the need for artificial pollination when the core recovery. Generally, fertility is poor. The germination strength is $71 \%$.

The temperature requirement of the geranium moves within wide limits. Optimum temperature is 16 $18{ }^{\circ} \mathrm{C}$ day and night of $12-14{ }^{\circ} \mathrm{C}$ vegetative periods. During cuttings it is $20^{\circ} \mathrm{C}$, but it can withstand $25-30$ ${ }^{\circ} \mathrm{C}$ during the summer planting. It then blooms with the most intense water supply. The optimum temperature of the hybrid varieties is $18-24{ }^{\circ} \mathrm{C}$ (Dobay, 1998).

In addition to the optimal light conditions, the geranium develops and blooms favorably. With 25,000 lux illumination both in cultivation and outdoors, there is rapid growth, rich in flowering, rich in branching, stem does not stretch. It does not damage the 50,000 lux light when the required water content is available in the soil (Nagy, 1991).

Most of the geranium species live in their natural habitat in a dry, whimsical precipitation distribution area. Relative humidity should not exceed $70-75 \%$ in the glasshouse and foil. Particularly in the cool, dark, winter months, night and morning condensation are dangerous. If the temperature reaches the dew point, the water will precipitate on the glass, foil and drop into the plants, leading to the spread of the Botrytis (Glits et al., 1997; Glits and Folk, 2000). Winter irrigate geranium enough for 2-3 weeks.

The geranium species live in their original habitat on sandy humus soil. In cultivation, soil is not particularly demanding, just like other ornamental plants. The soils in the $\mathrm{pH}$ range of 6.3-7.2 are ideal. Nitrogen, phosphorous and potassium-rich, but excessive $\mathrm{N}$ content causes strong vegetative development, hindering flowering. The $\mathrm{N}$ deficiency causes short leaves with small leaves. Lime-rich sensitive, it induces chlorosis in plants. In the soil, the salt concentration cannot rise above $0.5 \%$ otherwise the lower leaves will be smothered by salt suffocation. Effective defense is frequent, abundant, relieving irrigation. Rooting medium consists of $70-80 \%$ peat, $20-30 \%$ clay minerals, $10-20 \%$ bark $+2.5-3 \mathrm{~kg} \mathrm{~m}^{-3}$ carbonated lime $+0.5 \mathrm{~kg} \mathrm{~m}^{-3}$ complex fertilizer (Nagy, 1975).

Soil disinfection is inevitable because the source of soil used in propagation and cultivation is very high. In addition to soil-fungi, bacteria and weeds, we find viral infected plant parts in the soil. The soil is disinfected by steaming at high temperatures at $92-95{ }^{\circ} \mathrm{C}$ for $4-6$ hours (Gerbár, 1992).

The aim of the experiment is to determine what fungal diseases occur during the study period and what fungicides we can effectively control.

\section{MATERIALS AND METHODS}

The research was carried out in a Gyenes Flower gardening between 2016 and 2017 in Kecskemét. The gardening was founded in 1978, initially for gerbera (Gerbera) and yucca (Yucca) were their main crops, but switched to the geranium (Pelargonium) cultivation as a result of market (Figure 1 and Figure 2). 
Figure 1: Geranium seedlings

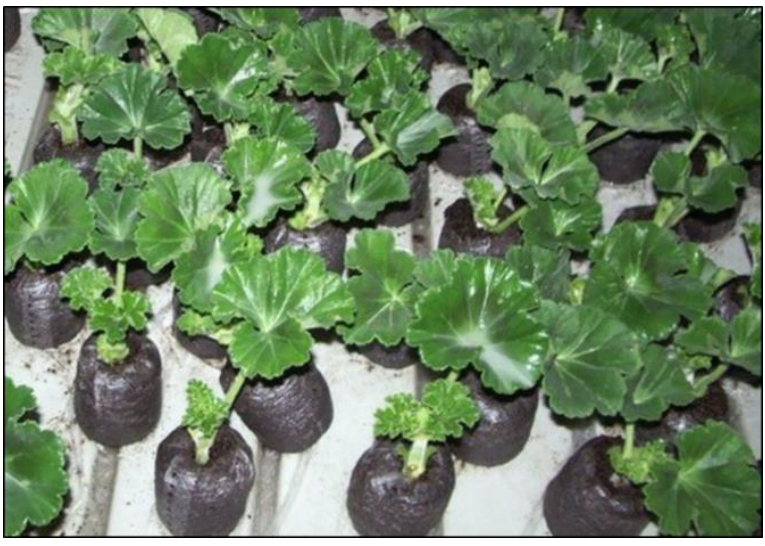

Figure 2: Experiment location

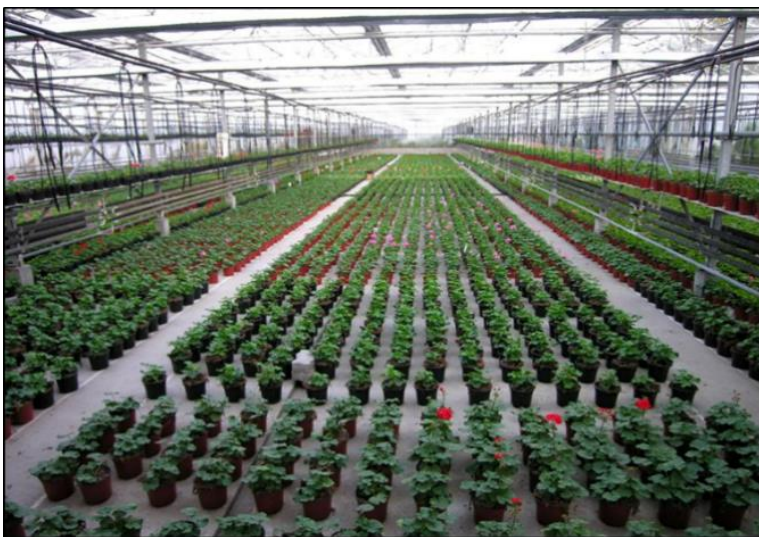

The Gyenes Flower gardening distributed by Klasmann-Deilmann GmbH, Germany Company, Klasmann TS 3 types of peat used in the cultivation of geranium. The composition of Klasmann TS 3 is a medium decomposed white filler, 0-25 mm; chemical properties: $\mathrm{pH}\left(\mathrm{H}_{2} \mathrm{O}, \mathrm{v} / \mathrm{v}\right.$ 1: 2.5) 6.0; Nutrient content $(\mathrm{g} / \mathrm{l}): 1.0$ and added nutrients: Nitrogen (mg N/l) 140; Phosphorus ( $\mathrm{mg} \mathrm{P}_{2} \mathrm{O}_{5} / \mathrm{l}$ ) 100; Potassium (mg $\mathrm{K}_{2} \mathrm{O} / \mathrm{l}$ ) 180; Magnesium (mg Mg/l) 100; Fe 13\% EDTA. Physical properties: dry matter content $<10 \%$, water capacity $75-80 \%$, air capacity $10-15 \%$ (http1).

The study was set up in 1,000-1,000 pieces of geraniums each year. The following pathogens have damaged the geranium stock: Botrytis cinerea, Pythium debaryanum, but rarely occurred Alternaria porri, Phytophthora cryptogea. The fungicides used in the experiment are listed in Table 1.

Table 1

The following fungicides were used in plant protection of geranium cultivation

\begin{tabular}{lll}
\hline Year & Fungicide & Active ingredient \\
\hline 2016 & Signum & boscalid + pyraclostrobin \\
& Amistar Top & azoxystrobin + difenoconazole \\
& Polyram & metiram \\
& Dithane & mancozeb \\
\hline 2017 & Signum & boscalid + pyraclostrobin \\
& Amistar Top & azoxystrobin + difenoconazole \\
& Polyram & metiram \\
\hline
\end{tabular}

\section{RESULTS}

During the experiment, the greatest damages were caused by botrytis (Botrytis cinerea). In addition, significant damage was caused by the fungal disease Pythium debaryanum, too. The chemical protection was carried out from March to November in both years (Figure 3). The results are summarized in Table 2 and Table 3.

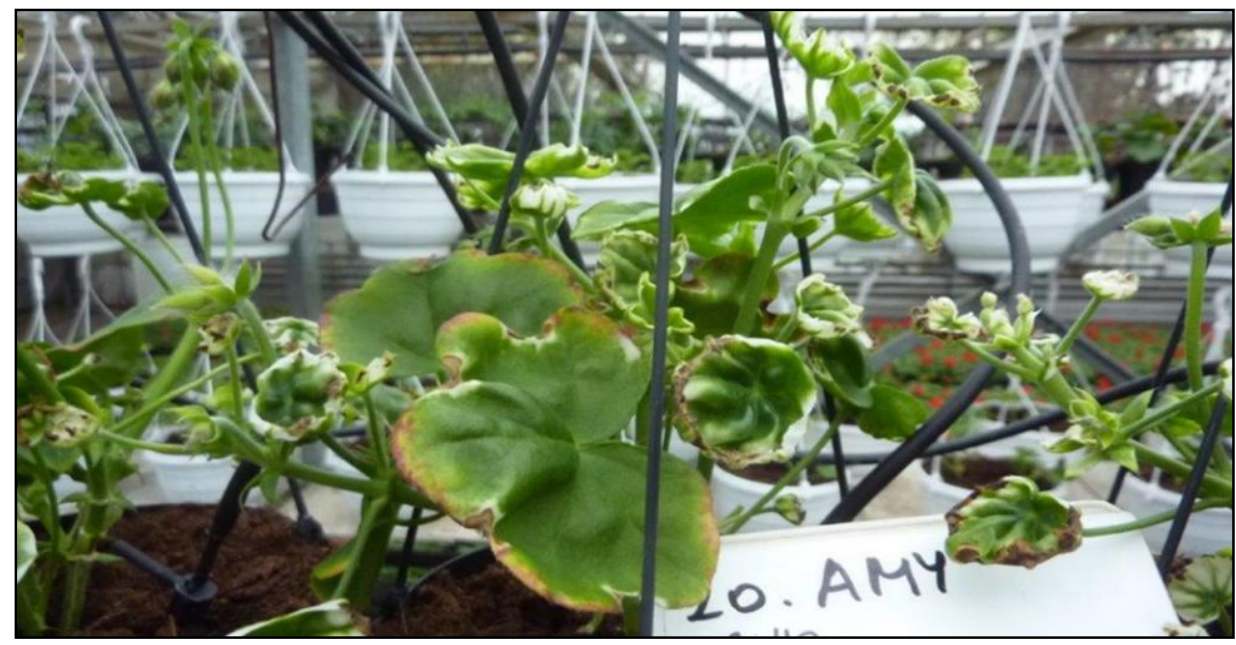


Table 2

Geranium (Pelargonium) pathological results of 2016

\begin{tabular}{lcc}
\hline Pathogens & Year & Total Geranium \\
& $\mathbf{2 0 1 6}$ & $\mathbf{1 , 0 0 0}$ \\
\hline Botrytis cinerea & $30 \%$ & 300 \\
Pythium debaryanum & $8 \%$ & 80 \\
Other fungal diseases & $4 \%$ & 40 \\
\hline Total diseases & $42 \%$ & 420 \\
\hline
\end{tabular}

Geranium (Pelargonium) pathological results of 2017

\begin{tabular}{lcc}
\hline Pathogens & Year & Total Geranium \\
& $\mathbf{2 0 1 7}$ & $\mathbf{1 , 0 0 0}$ \\
\hline Botrytis cinerea & $29 \%$ & 290 \\
Pythium debaryanum & $7 \%$ & 70 \\
Other fungal diseases & $2 \%$ & 20 \\
\hline Total diseases & $38 \%$ & 380 \\
\hline
\end{tabular}

The Signum and Amistar Top fungicides were the most effective against Botrytis cinerea. Viral and bacterial diseases did not occur during the period under review.

\section{DISCUSSIONS}

Our study was carried out in 2016 and 2017 in a horticulture in Kecskemét, Hungary. During the experiment, the greatest damages was caused by botrytis (Botrytis cinerea). The Signum and Amistar Top fungicides were the most effective against of $B$. cinerea.

In addition to the use of fungicides, we increased the spatial position of geraniums, early irrigation and frequent ventilation to ensure successful control. By 2017, we were able to reduce the damage caused by pathogens by 4 percent.

\section{ACKNOWLEDGEMENTS}

This work was supported by Gyenes Flower gardening in Kecskemét (Bács-Kiskun County). Special thanks to student Nóra Pap.

\section{REFERENCES}

Dobay, I. (1998): Pelargonium - geraniump. In: Sarolta Czáka (ed.): Potted ornamental plants. Agriculture Publisher, Budapest 300. p. $92-112$.

Gerbár, J. (1992): Geranium. Agriculture Publisher, Budapest. $97-$ 120.

Glits, M.-Folk, Gy. (2000): Horticultural plant pathology. Agriculture Publisher, Budapest. 502-507.

Glits, M.-Horváth, J.-Kuroli, G.-Petróczi, I. (1997). Plant protection. Agriculture Publisher, Budapest. 457-460.

Honfi, P.-Szántó, M.-Tillyné Mándy, A. (2011): Geraniums. Cser Publisher, Budapest. 10-14.
http1://portal.nebih.gov.hu/documents/10182/287730/Klasmanncsal ad.pdf/bd7c2190-f421-41bc-b2b7-36336d29f271 (April 2018)

Nagy, B. (1975): Growing of ornamental plants. Agriculture Publisher, Budapest. 263-269.

Nagy, B. (1991): Pelargonium (Geraniaceae) - Geranium.. In: Annual flowers. Agriculture Publisher, Budapest. p. 127., 94-95. Szántó, M.-Mándy, A.-Fekete, Sz. (2003): Pelargonium. In: Flower beds and balconies. Association of Westphalian Diving Schools, Szombathely. 128 p.; 38-39, 70-73. 
